\title{
EFFICIENCY OF KAROFLAVIN USE IN HEPATOSES OF BROILERS
}

\author{
V. N. Karaichentsev", V. V. Semenyutin, A. V. Kolesnikov, L. V. Reznihenko, R. A. Merzlenko, \\ S. B. Noskov, A. A. Reznihenko, E. G. Yakovleva
}

Federal State Budgetary Educational Institution of Higher Education «Belgorod State

Agricultural University named after V. Gorin»

Published online: 08 August 2017

\begin{abstract}
Relevance In recent years, the negative role of some pharmaceuticals effect on the liver of an agricultural bird which hepatotoxicity sharply increases in theprocess of biotransformation in the connection with the formation of active metabolites was revealed. Poisoning with xenobiotics and hormone and protein metabolites accumulating in an organism causes intoxication and promotes increase in intensity of peroxide lipid oxidation. Therefore, biooxidantsuse which include fat- and water-soluble vitamins is necessary. Considering this, together with the staff of CJSC Petrokhim we developed a new complex drug which contained carotene, bioflavonoid complex of a larch, and fat-soluble vitamins. The drug was called Karoflavin.

The purpose of the work was to study the possible use of karoflavin inbroilers with hepatosis.

Results of the study The obtained resultsshowed highgrowth stimulating activity and biological availability of karoflavin, and its hepatoprotective properties. After karoflavin use bird average daily body-weight increased by 9.5 and $10.3 \%$, while forage use decreased by 1.1 and $1.6 \%$, calcium serum blood level increased by 35.0 and $35.9 \%$, vitamin A increased by 20.3 and $25.6 \%$, aspartateaminotransferase activity decreased by 20.3 and $21 ю 1 \%$, alanineaminotransferases - by 20.3 and $22.9 \%$, glucose level decreased by 26.1 and $25.6 \%$.
\end{abstract}

Author Correspondence, e-mail: reznichenko2008@rambler.ru

doi: http://dx.doi.org/10.4314/jfas.v9i2s.864 
Conclusions Karoflavin is proposed to enter into diets of broilers for the prevention of hepatoses at the rate of $1.0 \mathrm{~g} / \mathrm{kg}$ of body weight during the whole period of broiler growing.

Keywords: Karoflavin, carotene, vitamins, bioflavonoidny complex of a larch, broilers, diets, hepatoses.

\section{INTRODUCTION}

Liver damages of different etiology are rather important in the general structure ofagricultural bird diseases and are widespread pathology $[1,19]$.

Many authors consider that exogenous causes prevail in the development of liver dystrophy in growing birds [18]. Some researchers specify that fodder intoxication of the organism resulting from feeding of birds withlow-grade forages [3] is the main cause.

Gastroenteritis develops in chickens on the background of liver toxic dystrophy. At the same time, the scheme of treatment containsantimicrobial agents including those with hepatotoxic action that aggravates pathological process in the organism [5].

High intensity of lipid peroxide oxidation and decrease of antioxidant protection was found to be one of pathogenesis components in liver diseases. Thus, it is expedient to use antioxidant drugs for treatment and prevention of these diseases. In poultry farming vitamin $\mathrm{E}$ is traditionally considered to be such a drug, which is used in the form of synthetic tocopherol acetate added to a forage [15]. There are data that synthetic drugs not always produce in the organism physiologic effect common to vitamin E [4.].

Therefore, development of the preventive actions based on elimination, both causes of toxic injuries of the liver, and the main components of pathogenesis is quite urgent.

Many authors point consider acute and chronic stresses which are followed by decrease in natural resistance and immune responsiveness, as the main cause in developing of these diseases [17].

Negative influence of some drugs, mycotoxins and other ecotoxicants which hepatotoxicity sharply increases in the organism in the course of biotransformation due to the formation of active metabolites [10] was established.

Toxic substancesentering the organism with a forage and those formed in cases of digestive disorders and intermediaryexchange,absorbed in the blood and reaching the liver, directly influence hepatocytes. Depending on quantity and period of their entrance in the parenchyma, activity of oxidizing enzymes decreases, glycogen level sharply falls, fatty infiltration develops, 
disintegration of hepatic cells and their necrosis is observed.Toxin excessive accumulation in the organism, inability of detoxication physiological systems to provide their effective clearanceresults inthe organism endogenous intoxication[6].

According to S. B. Matveev [7], it is midmolecule substances that are a universal biochemical marker of endogenous intoxication. Such substances are intermediate and end products of the normal and disturbed protein and lipid metabolism. They accumulate in the organism in the quantities exceeding normal concentrations and are the products of free radical lipid peroxide oxidation, intermediate metabolism, midmoleculepeptides [1, 11].

To correct cytolytic syndrome it is expedient to include in modern pharmacotherapy of chronic liver damages drugs with hepatoprotective and membrane stabilizing action that can be done by the activation of antioxidant systems, in particular by using antioxidants [16,11,9] to which carotene, fat-soluble vitamins, bioflavonoids, etc. belong [13,14]

Therefore, the problem of research of the new effective drugs combining the immunostimulating, antioxidant and anti-inflammatory properties is very urgent in spite of the fact that many drugs for this pathology are available.

Considering the above, together with scientists-chemists of CJSC Petrokhim (Belgorod)we developed a new complex drug which include carotene, bioflavonoid complex of a larch, and fatsoluble vitamins which was termedKaroflafin.

The purpose of the work wasto study karoflavin influence on broilers organism in order to suggest it as a prophylactic drug in hepatoses of an agricultural bird.

To realize the purpose the following taskstasks were set:

- to estimate broilers growth intensity after use of karoflavin;

- to analyze blood biochemical changes;

- to study natural resistance of the organism.

\section{MATERIAL AND METHODS}

Karoflavin served the object of the study. Drug was developed by the staff of CJSC Petrokhim (Belgorod).

The drugis a loose powdery mass of yellow-orange color andcontainsbeta-carotene- $3.3 \mathrm{mg} / \mathrm{g}$; larch bioflavonoids - $20 \mathrm{mg} / \mathrm{g}$; vitamin A - $500 \mathrm{ME} / \mathrm{g}$; vitamin $\mathrm{D}_{3}-250 \mathrm{ME} / \mathrm{g}$; vitamin E - 0.2 $\mathrm{mg} / \mathrm{g}$; vitamin $\mathrm{F}-0.05 \mathrm{mg} / \mathrm{g}$. 
The drug was studiedin broilers. Changes in protein, carbohydrate and mineral metabolism were used determine the nature of karoflavin influence on the organism of a bird. Safety of a livestock and average daily body-weight increase were considered.

Blood was taken from the auxiliary vein. Biochemical parameters were determined by the standard methods. Hitachi hematology analyzer was used.

The results of the study were mathematically processed [12] calculating arithmetic means (M), their average mistakes (m) and confidence coefficient (p); digital data were analyzed using Fischer-Studenttest. Distinctions were considered to be significant at $p<0.05$. Parametrical methods of reliability of the results of statistical analysis [8] were determined by the relation of a difference of coefficients to mean error of this difference. Distinctions were considered reliable if a difference of relative coefficients was 2 and more times more than mean error of a difference.

\section{RESULTS AND DISCUSSION}

To determine karoflavin influence on broilers' organism and an optimum dose of the drug following analogue principle 4 groups of 7-day-old broilers 60 birds in each group were formed. The first group was control and was fed by the diet used in the economy. In tests, karoflavin was added to the chickenfeed at the rate of $0.5,1.0$ and $2.0 \mathrm{~g} / \mathrm{kg}$ of body weight respectively within 30 days.

The scheme of the experiment is presented in table 1.

Table 1. The scheme of the experiment on broilers

\begin{tabular}{|c|c|c|}
\hline Groups & The drug used & Dose \\
\hline $1-$ control & Mainration (MR) & \\
\hline $3-$ test & MR+karoflavin & $0.5 \mathrm{~g} / \mathrm{kgbody}$ weight \\
\hline $4-$ test & MR+karoflavin & $1.0 \mathrm{~g} / \mathrm{kgbody}$ weight \\
\hline $5-$ test & MR+karoflavin & $2.0 \mathrm{~g} / \mathrm{kgbody}$ weight \\
\hline
\end{tabular}

The results showed positive influence of karoflavin on the organism of birds (tab. 2). At the end of the experimental period chicken survival rate was $98.3 \%$ in the third and fourth groups, in the second test group it was $96.6 \%$, and in control group - 95\%. The highest average daily growth also was in the third and fourth test groups where applied the maximum doses of the drug (for 
9.5\% and $10.3 \%$ above control), as for the second test group where the dose of karoflavin was minimum, the average daily gain of chickens made $50.9 \mathrm{~g}$ that is $3.0 \%$ higher than in the control group.

Table 2. Results of karoflavin test in broilers

\begin{tabular}{|l|c|c|c|c|}
\hline \multirow{2}{*}{\multicolumn{1}{|c|}{ Parameters }} & \multicolumn{4}{c|}{ Groups } \\
\cline { 2 - 5 } & 1-control & 2-test & 3-test & 4-test \\
\hline $\begin{array}{l}\text { Number of birds at the } \\
\text { beginning of the experiment }\end{array}$ & 60 & 60 & 60 & 60 \\
\hline At the end & 57 & 58 & 59 & 59 \\
\hline Survival rate, \% & 95.0 & 96.6 & 98.3 & 98.3 \\
\hline $\begin{array}{l}\text { Averagedailybody-weight } \\
\text { increase, g }\end{array}$ & 49.4 & 50.9 & 54.1 & 54.5 \\
\hline tto control, \% & - & +3.0 & +9.5 & +10.3 \\
\hline $\begin{array}{l}\text { Feed consumption for 1 kg of } \\
\text { body-weight increase, } k g\end{array}$ & 1.81 & 1.79 & 1.78 & 1.78 \\
\hline tto control, \% & - & -1.1 & -1.6 & -1.6 \\
\hline
\end{tabular}

Thus, the study show high growth-stimulating karoflavin efficiency, especially after maximum doses of the drug.

Analyses of blood biochemical composition (tab. 3) showed increase ofcalcium blood serum level in chickens of the test groups: in the second - by 24.2, in thirds - 35.0 and in the fourth $35.9 \%$; the difference with control was confirmed statistically only after maximum doses of the drug $(\mathrm{p}<0.05)$. 
Table 3. Biochemical parameters of broilers blood

\begin{tabular}{|c|c|c|c|c|}
\hline \multirow[b]{2}{*}{ Parameters } & \multicolumn{3}{|c|}{ Groups } & \multirow[b]{2}{*}{ 4-test } \\
\hline & 1- control & 2-test & 3-test & \\
\hline \multicolumn{5}{|c|}{ Initial data } \\
\hline Total protein, $g / L$ & $24.2 \pm 1.28$ & $24.1 \pm 1.27$ & $23.9 \pm 1.29$ & $24.6 \pm 1.47$ \\
\hline Calcium, $\mathrm{mmol} / \mathrm{L}$ & $3.20 \pm 0.35$ & $3.21 \pm 0.26$ & $3.11 \pm 0.48$ & $3.26 \pm 0.30$ \\
\hline Phosphorus, $\mathrm{mmol} / \mathrm{L}$ & $2.67 \pm 0.51$ & $2.77 \pm 0.34$ & $2.72 \pm 0.41$ & $2.67 \pm 0.50$ \\
\hline ChoLesteroL, $\mathrm{mmol} / \mathrm{L}$ & $1.44 \pm 0.40$ & $1.47 \pm 0.48$ & $1.40 \pm 0.36$ & $1.38 \pm 0.52$ \\
\hline GLucose, $\mathrm{mmol} / \mathrm{L}$ & $14.13 \pm 0.71$ & $13.67 \pm 0.50$ & $13.48 \pm 0.71$ & $13.39 \pm 0.65$ \\
\hline Vitamin A, $\mathrm{mcmol} / \mathrm{L}$ & $1.36 \pm 0.18$ & $1.38 \pm 0.11$ & $1.37 \pm 0.14$ & $1.35 \pm 0.10$ \\
\hline $\mathrm{AST} u / \mathrm{L}$ & $259.2 \pm 5.67$ & $258.4 \pm 6.37$ & $260.1 \pm 6.77$ & $260.9 \pm 6.34$ \\
\hline $\mathrm{ALT} \mathrm{u} / \mathrm{L}$ & $61.3 \pm 1.21$ & $61.7 \pm 2.34$ & $61.6 \pm 2.42$ & $62.2 \pm 2.32$ \\
\hline \multicolumn{5}{|c|}{ After the druguse } \\
\hline Total protein, $g / L$ & $25.6 \pm 1.38$ & $27.4 \pm 1.41$ & $28.2 \pm 1.33$ & $27.9 \pm 1.41$ \\
\hline Calcium, $\mathrm{mmol} / \mathrm{L}$ & $3.31 \pm 0.27$ & $4.11 \pm 0.36$ & $4.47 \pm 0.33^{*}$ & $4.50 \pm 0.32 *$ \\
\hline Phosphorus, $\mathrm{mmol} / \mathrm{L}$ & $2.81 \pm 0.32$ & $2.67 \pm 0.33$ & $2.74 \pm 0.36$ & $2.49 \pm 0.29$ \\
\hline CholesteroL, $\mathrm{mmol} / \mathrm{L}$ & $1.60 \pm 0.21$ & $1.54 \pm 0.32$ & $1.48 \pm 0.29$ & $1.47 \pm 0.21$ \\
\hline Glucose, $\mathrm{mmol} / \mathrm{L}$ & $13.29 \pm 0.82$ & $12.76 \pm 0.64$ & $9.82 \pm 0.90^{*}$ & $9.84 \pm 0.87 *$ \\
\hline Vitamin A, mcmol/L & $1.33 \pm 0.07$ & $1.39 \pm 0.09$ & $1.64 \pm 0.08 * *$ & $1.67 \pm 0.09 * *$ \\
\hline $\mathrm{AST} \mathrm{u/L}$ & $251.8 \pm 7.10$ & $239.9 \pm 8.82$ & $200.5 \pm 6.98 * *$ & $198.7 \pm 7.46^{* *}$ \\
\hline $\mathrm{ALT} \mathrm{u/L}$ & $62.4 \pm 2.82$ & $56.9 \pm 3.31$ & $49.7 \pm 2.68 *$ & $48.1 \pm 3.10 *$ \\
\hline
\end{tabular}

* - p $\square \square \square \square \square ; \square * *$ - p $\square \square \square \square \square \square \square$

At the end of the experimental period, there was an increase in vitamin A by $23.3 \%$ in the third and by $25.6 \%$ in the fourth group; the difference with control was confirmed statistically.

Before the drug use, increase of interlamination and glucose enzymes activity was noted in blood serum of chickens of all groups. Karoflavin use prevented this pathological process. Thus, at the end of the experimental period maximum doses of karoflavin decreased the activity of aspartateaminotransferase by 20.3 and $21.1 \%$ and alanineaminotransferase by 20.3 and $22.9 \%$, 
and glucose by 26.1 and $25.6 \%$ in the third and fourth test groups respectively, in all cases $p$ $<0.05-0.01$.

These changes demonstrate positivekaroflavin influenceon liver and pancreas function restoration. In healthy animals,enzyme concentration in hepatocytes is much higher, than in blood serum. When hepatocytes are injured this plasma and cellular gradient is sharply disturbed. Liver parenchyma cytolysis is followed by the increase in permeability of hepatocytes cellular membranes and cellular organelle membranes;cytoplasm, mitochondria, lysosome enzymes are transported to the circulatory bed.

Thus, in karoflavinin the doses studied positively influences bird organism, however a dose of $1.0 \mathrm{~g} / \mathrm{kg}$ of body weight should be considered optimum as economic profitable.

Upon termination of the experiment chickens were sacrificed and vitamin A content was determined in their liver(fig. 1).

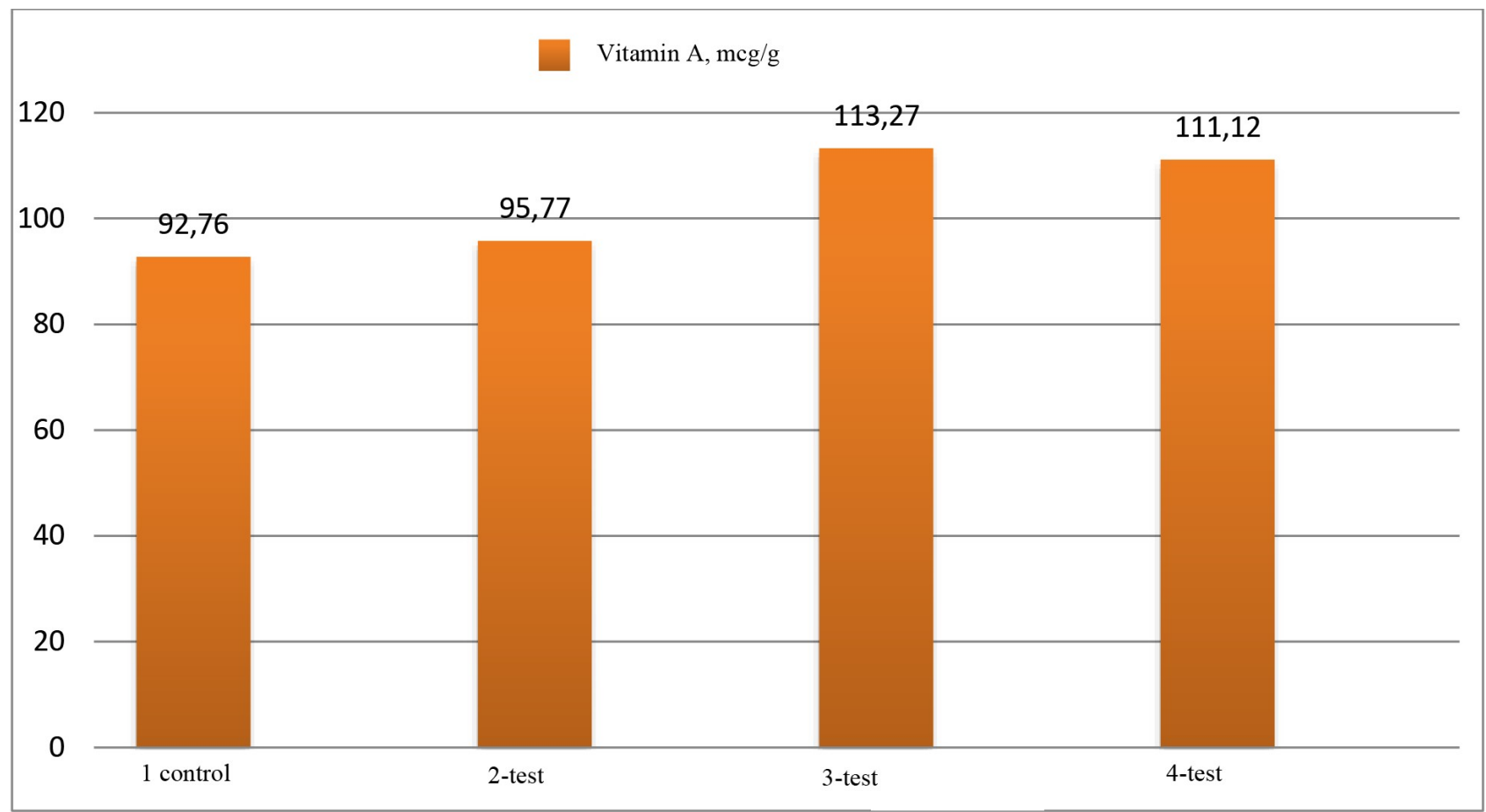

Fig.1. Vitamin A level in the liver of broilers

Karoflavin maximum doses caused significant vitamin A level increase in the liver of chickens of the third and fourth test groups by 22.1 and $19.8 \%$ (in all cases $\mathrm{p}<0.01$ ).

Thus, 1.0 and $2.0 \mathrm{~g} / \mathrm{kg}$ of body weight are optimum karoflavin doses for birds, $1.0 \mathrm{~g} / \mathrm{kg}$ of body weight should be regarded as economically proficient. 
The level of natural resistance of a bird organism studied by the activity of lysozyme and blood serumbactericidal activity, phagocytic activity of pseudo-eosinophils and serum immunoglobulin content (fig. 2).

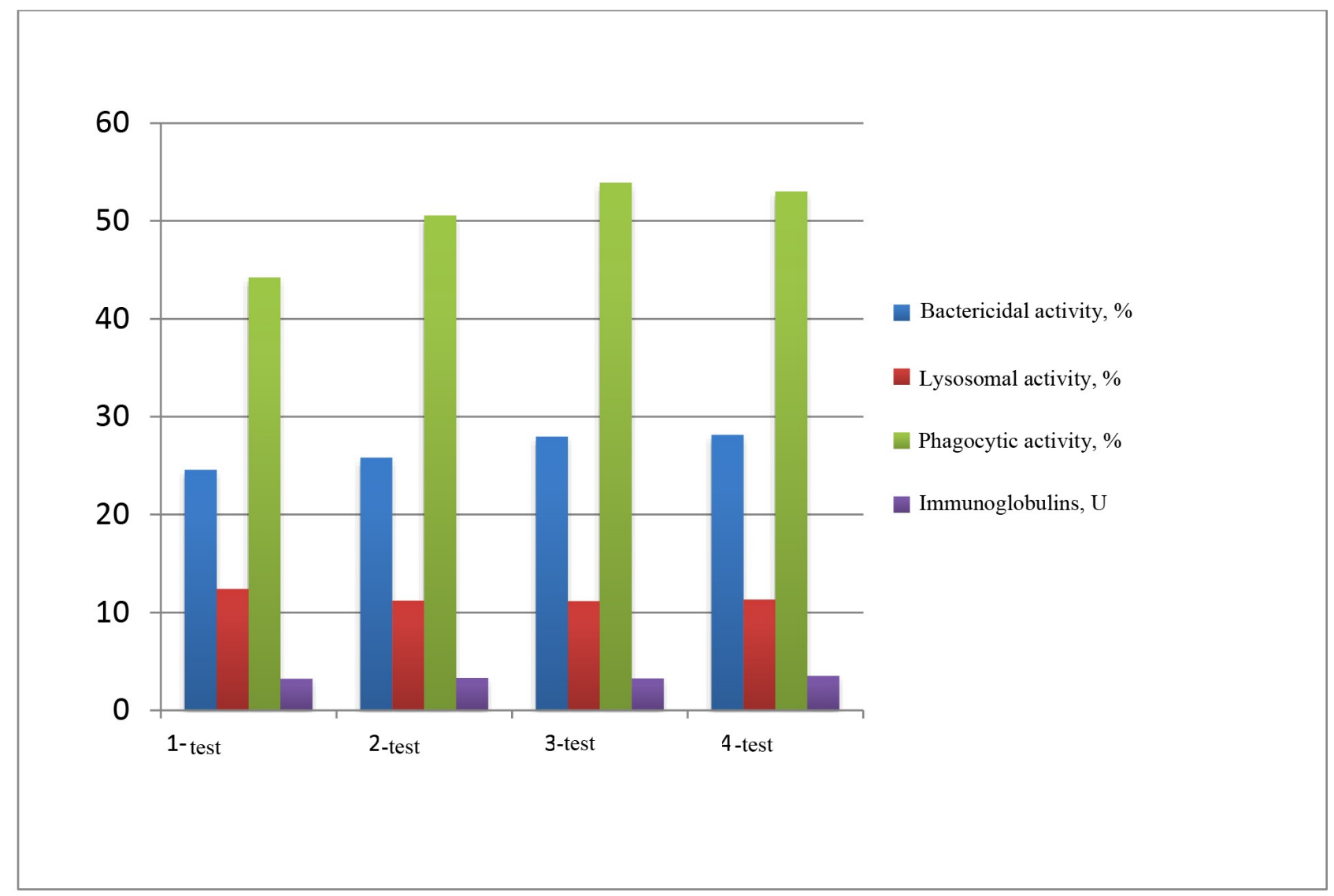

Fig.2. Parameters of natural resistance of broilers

Blood serum lysozyme and bactericidal activity allows to estimate nonspecific humoral protection of the organism;pseudo-eosinophil phagocytic activity reflects cellularimmune factors state; serum immunoglobulins level characterizes humoral immunity system in general.

Data in the figure show that karoflavin maximum doses caused significant increase in phagocytic activity of pseudo-eosinophils in chickens of the third and fourth test groups (by 21.9 and 19.8\%, $\mathrm{p}<0.05$ ) in comparison with the control data and a tendency of increase in blood serum bactericidal activity increase.

Thus, the performed study showed that karoflavin has high pharmacological activity. It increases some factors of natural resistance of an organism and, as a result, increases average dailybody- 
weight increase and survival of broilers. The obtained results showedof all doses studied optimum was $1.0 \mathrm{~g} / \mathrm{kg}$ of body weight. Higher dose $(2 \mathrm{~g} / \mathrm{kg})$ does not give an essential bodyweight and immune status increase, and the low dose $(0.5 \mathrm{~g} / \mathrm{kg})$ is less effective. Therefore, it is necessary to consider optimum dose of $1.0 \mathrm{~g} / \mathrm{kg}$ of body weight.

\section{CONCLUSION}

The performed study showed high biological availability of the drug and its positive influence on physiological state of a bird which consists of normalization of carbohydrate and mineral metabolism and liver function improvement.

Thus, the broilers should be recommended karoflavin in a dose of $1.0 \mathrm{~g} / \mathrm{kg}$ of body weight during the entire period of birds growth as hepatoprotective means, a stimulator of body-weight increase and as a source of vitamins.

\section{THE LIST OF THE USED LITERATURE}

1. Vladimirov, YU.A. Free radicals in biological systems//Sorosovsky educational magazine.V. 6, No. 9, 2000, page 13 - 19.

2. Vinogradova,L.F., Mirzoyan Zh. A., Kharlitskaya E. V., Manyakina N. S. Excretory liver function restoration by antioxidants in toxic hepatitis//RUDN Bulletin, the Medicine series, 2000, No. 2, page 53 - 55 .

3. Vlasova, S. N. Liver monooxygenase system in chronic hepatitis according to the antipyrine test / S. N. Vlasova, I. A. Pere-slechina, E. I. Shabunin//Klien. lab. diagnostics. 1993.-№ 4. - page 41-43.

4. Dudin, V. I. Vitamin E biochemistry and related biologically active substances / V. I. Dudin. - M.: Russian Academy of Agrarian Sciences, 2004. - 256 pages.

5. Emelyanov, V. V. Medicinal hepatitis in pigs / V. V. Yemelyanov, I. Z. Sevryuk//Scientists of a note of the Vitebsk state academy of the award "Honour Sign" of veterinary medicine. - Vitebsk, 2005. t. 41, p.1. - page 46-49.

6. Katikova, O. Yu. Mexidol influence on homeostasis and lipid peroxide oxidationin paracetamolintoxication //Experim. and clinical pharmacology. - 2002. - V.65, No. 5. - 53-56. 
7. Matveev, S. B. Evaluation of endogenous intoxication due to indicators of midmolecular peptides in emergencies / S. B. Matveev, N. F. Fedorova, M. A. Godkov//Clinical laboratory diagnostics. - 2009. - No. 5. - Page 16-18

8. Merkovs, A.M. Sanitary statistics / A.M. Merkov, L. E. Polyakov. - L.: Medicine, 1974. 383 pages.

9. Mukhina, N. V. Fodder and biological feed additives for animals / N. V. Mukhina. M.: Kolos. - C, 2008. - 271 pages.

10. Myshkin, VA. Correction of lipid peroxide oxidation in experimental intoxications by different chemicals.//Author's abstract. Dis. medical sciences. - Chelyabinsk. - 1998.-46 C.

11. Lipid peroxide oxidation, its role in pathogenesis of diseases of animals, ways of correction: monograph / S. S. Abramov [etc.]. - Vitebsk: VGAVM, 2007.-154 pages.

12. Plokhinsky, N. A. Biometry / N. A. Plokhinsky. - M.: Moscow university publishers, 1987. - 367 pages.

13. Reznichenko L. V.Efficiency of carotene-containing drugs in broiler poultry farming / L.V. Reznichenko, S. P. Kolesnichenko, V. A. Syrovitsky//Materials of the international scientific-production conference devoted to the 100 anniversary of the Honored worker of science of RSFSR, doctor of veterinary sciences, professor Kabysh A. A.: Collection of research papers. - Troitsk: Southern Ural GAU, 2017 - Page 344-350.

14. Sergeyev, E.O. Flavonoids influence on oxidizing stress mechanisms development in toxic liver damages.Author's abstract of thesis for the degree of Candidate of pharmacological sciences. Pyatigorsk, 2007. - 202 pages.

15. Khlebus, N. K. Toxic liver damages in pigs in conditions of an industrial complex and their prevention with the use of natural tocopherol / N. K. Hlebus S. V. Petrovsky//Bulletin of VGAVM - 2011. - V.47, Issue 2, P. 227-231.

16. Carotinoids efficiency in toxic liver damage / E. V. Kuzminova, V. S. Solovyov, M. P. Semenenko, S. N. Nikolayenko//Works of the Kuban state agricultural university. Series: Veterinary sciences No. 1 (p. 2). - Krasnodar.-2009. - Page 117-119.

17. Borell, E. H. The biology of stress and its ap-plication to livestock housing and transportation assessment./E. H. von Borel1//J. Anim. Sci.-2001. - Vol. 79, No. 2 - E260-E267. 
18. Combined glutathione-S-transferase $\mathrm{M} 1$ and $\mathrm{T} 1$ genetic polymorphism and tacrine hepatotoxicity/Simon T, Becquemont L, Mary-Krause M, de Waziers I, Beaune P, FunckBrentano C. / Clin. Pharmacol. Ther. - 2000. - V. 67, No. 4. - River 432-437

19. Rikans, L. E., Cai Y., Hornbrook K. R. Allyl alcohol cytotoxicity in isolated rat hepatocytes: mechanism of cell death does not involve an early rise in cytosolic free calcium//Arch. Toxicol.-1994. - V. 69, No. 1. - River 24-29.

\section{How to cite this article:}

Karaichentsev V N, Semenyutin V V, Kolesnikov A V, Reznihenko L V, Merzlenko R A, Noskov S B, Reznihenko A A, Yakovleva E G. Efficiency of karoflavin use in hepatoses of broilers. J. Fundam. Appl. Sci., 2017, 9(2S), 1603-1613. 